\title{
Bilateral occipital calcification, epilepsy and coeliac disease: clinical and neuroimaging features of a new syndrome
}

\author{
A Magaudda, B Dalla Bernardina, P De Marco, Z Sfaello, M Longo, V Colamaria, \\ O Daniele, G Tortorella, M A Tata, R Di Perri, M Meduri
}

University of Messina, Italy, Institute of Neurological and Neurosurgical

Sciences, First

Neurological Clinic

A Magaudda

R Di Perri

Institute of

Radiological Sciences

$M$ Longo

Institute of Child

Neuropsychiatry

G Tortorella

Institute of Mental

Sciences

$M$ Meduri

Institute of Child

Neuropsychiatry,

University of Verona,

Italy

B Dalla Bernardina

$\checkmark$ Colamaria

Centro "Angeli

Custodi", Istituti

Ospedalieri, Trento,

Italy

P De Marco

Neuropediatrics

Department, Catholic

University of

Cordoba, Argentina

Z Sfaello

Institute of

Neuropsychiatry,

University of

Palermo, Italy

O Daniele

Department of

Neurophysiopathology,

University of Naples,

Italy

M A Tata

Correspondence to:

Dr Magaudda, Clinica

Neurologica $1^{\circ}$, Policlinico

Universitario, 98013

Contesse, Messina, Italy

Received 29 July 1991

and in final revised form

21 September 1992

Accepted 30 September 1992

\begin{abstract}
Twenty patients affected by bilateral occipital cortical-subcortical calcification (BOC) are described, 19 (95\%) had epilepsy. In 8 of 16 cases studied, intestinal biopsy revealed coeliac disease. Fourteen patients had occipital partial epilepsy with a relatively benign outcome, while 4 patients were affected by a severe form of epilepsy, with very frequent, drug-resistant, generalised and partial seizures with mental deterioration. One patient had a single episode of convulsive status epilepticus at four months of age. The neurological examination was normal in all patients. CT showed flocculo-nodular, cortico-subcortical BOC, without enhancement and without lobar or hemispheric atrophy. MRI was normal. The clinical and neuroimaging features of these patients are different therefore from those with the Sturge-Weber Syndrome. The study confirms a high prevalence of coliac disease in patients with BOC, but the relationship between these two pathologies still needs to be clarified.
\end{abstract}

(F Neurol Neurosury Psychiatry 1993;56:885-889)

The combination of epilepsy, bilateral occipital calcification (BOC) and coeliac disease (CD) is a recently described syndrome, ${ }^{1-3}$ whose clinical features and outcome have not been clearly defined.

We have traced reports of 36 patients ${ }^{4-19}$ affected by epilepsy whose CT image was unusual in showing cortical and subcortical calcification (Ca) located in both occipital regions; in 14 of them $C D$ was also detected. The occipital $\mathrm{Ca}$ were similar to those found in Sturge-Weber syndrome(SWs) but these patients showed none of the other typical symptoms of SWs: namely noevus flammeus, glaucoma and neurological deficit.

The aim of this study was to identify the clinical and neuroradiological features of the new syndrome and to clarify its distinction from SWs.

\section{Material and methods}

Our study group was composed of 20 patients, 11 females and 9 males, all of whom were found to have BOC. The mean age was 14.6 years (range 6-23 years) and the mean follow up time was 9.5 years (range 2-22 years). Each patient had complete ophthalmological and neurological examination, EEG and polygraphic recordings during wakefulness and sleep, and routine blood tests. In addition, we determined the blood levels of antiepileptic drugs, parathyroid hormone, calcitonin, and blood antibodies (TORCH complex). In 3 patients (cases 8, 9, and 15) blood folic acid level and serological HLA typing were also studied.

Sixteen patients had intestinal biopsy, whether or not they had clinical symptoms of malabsorption.

Cerebral CT was performed in all patients and repeated two or three times in 13 patients. Other special tests were performed as follows: skull radiographs (12 patients), MRI (8 patients), cerebral angioscintigraphy (5 patients), digital angiography (2 patients) and SPECT (2 patients).

\section{Results}

The main features of the 20 patients are summarised in the table.

Family history was irrelevant in 19 cases. One patient (case 8) had a sister affected by partial epilepsy, whose CT showed a unilateral calcification in the right occipital region.

Intellectual and neurological picture was normal in 19 patients. One patient (case 13) showed a bilateral reduction of the visual field.

Routine laboratory tests were normal in all patients. Folic acid level, tested in 2 patients affected by CD (cases 9 and 15) and in 1 patient without CD (case 8), was at the lower normal values.

Serological HLA typing in three patients was as follows: Case 8: A2, A10, B12, B35, Cw3, Cw4, DR2, DR7, DQw2; Case 9: A2, A3, B35, Cw4, DR3, DRw 11, DQw 2, DQw7; Case 15: A2, 一, B5, B13, CX5, DR7, DRw11, DRw52, DRw53, DQw2, DQw3.

\section{EPILEPSY}

Nineteen patients had epilepsy. Case 20 had never had epileptic attacks and BOC were incidentally detected on a skull radiograph performed after head trauma. Case 19 presented with convulsive status epilepticus at 4 months of age, but did not continue to have attacks. For the remaining 18 patients the mean age at seizure onset was 5.2 years (range seven months to 16 years). Four patients (cases $6,7,8$, and 10 ) had suffered from febrile convulsions. We divided the 
Table: Main features of 20 patients with BOC

\begin{tabular}{|c|c|c|c|c|c|c|c|c|c|}
\hline Pateints & Sex & $\begin{array}{l}\text { Age } \\
\text { (years) }\end{array}$ & $\begin{array}{l}\text { Age at seizure } \\
\text { onset }\end{array}$ & $\begin{array}{l}\text { Type of } \\
\text { epilepsy }\end{array}$ & $\begin{array}{l}\text { Age at } \\
\text { malabsorption } \\
\text { symptoms onset }\end{array}$ & $\begin{array}{l}\text { Intestinal } \\
\text { biopsy }\end{array}$ & $\begin{array}{l}\text { Neurological } \\
\text { examination }\end{array}$ & $\begin{array}{l}\text { Mental } \\
\text { retardation }\end{array}$ & $C T$ scan \\
\hline 1 & $\mathbf{M}$ & 15 & 7 months & Partial & 10 months & Coeliac disease & $\mathrm{N}^{\star}$ & No & \multirow{2}{*}{$\begin{array}{l}\text { BOC }++ \text { Bilateral } \\
\text { frontal } \mathrm{Ca} \\
\text { BOC }\end{array}$} \\
\hline 2 & $\mathbf{F}$ & $15 \cdot 5$ & 4 years & Partial & No malabsorption & Not performed & $\mathbf{N}$ & No & \\
\hline $\begin{array}{l}3 \\
4\end{array}$ & $\begin{array}{l}\mathrm{M} \\
\mathrm{F}\end{array}$ & $\begin{array}{l}16 \cdot 5 \\
16\end{array}$ & $\begin{array}{l}4 \text { years } \\
1 \text { year }\end{array}$ & $\begin{array}{l}\text { Partial } \\
\text { Partial }\end{array}$ & $\begin{array}{l}6 \text { months } \\
\text { No malabsorption } \\
\text { symptoms }\end{array}$ & $\begin{array}{l}N^{\star} \\
\text { Not performed }\end{array}$ & $\stackrel{\mathbf{N}}{\mathbf{N}}$ & $\begin{array}{l}\text { No } \\
\text { No } \\
\text { No }\end{array}$ & \multirow{2}{*}{$\begin{array}{l}\text { BOC } \\
\text { Boc + right } \\
\text { fronto- } \\
\text { parietal Ca } \\
\text { BOC }\end{array}$} \\
\hline 5 & $\mathbf{F}$ & 20 & 5 years & Partial & $\begin{array}{l}\text { No malabsorption } \\
\text { symptoms }\end{array}$ & $\mathbf{N}$ & $\mathbf{N}$ & No & \\
\hline $\begin{array}{l}6 \\
7 \\
8\end{array}$ & $\begin{array}{l}M \\
F \\
F\end{array}$ & $\begin{array}{l}12 \\
22 \\
13\end{array}$ & $\begin{array}{l}7 \text { years } \\
16 \text { years } \\
11 \text { years }\end{array}$ & $\begin{array}{l}\text { Partial } \\
\text { Partial } \\
\text { Partial }\end{array}$ & $\begin{array}{l}8 \text { months } \\
12 \text { months } \\
\text { No malabsorption }\end{array}$ & $\begin{array}{l}\mathbf{N} \\
\text { Coeliac disease } \\
\mathbf{N}\end{array}$ & $\begin{array}{l}\mathbf{N} \\
\mathbf{N} \\
\mathbf{N}\end{array}$ & $\begin{array}{l}\text { No } \\
\text { No } \\
\text { No }\end{array}$ & $\begin{array}{l}\text { BOC } \\
\text { BOC } \\
\text { BOC }\end{array}$ \\
\hline $\begin{array}{r}9 \\
10\end{array}$ & $\mathrm{~F}$ & $\begin{array}{r}13 \\
6\end{array}$ & $\begin{array}{l}7 \text { years } \\
3 \text { years }\end{array}$ & $\begin{array}{l}\text { Partial } \\
\text { Partial }\end{array}$ & $\begin{array}{l}\text { symptoms } \\
1 \text { year } \\
\text { No malabsorption } \\
\text { symptoms }\end{array}$ & $\begin{array}{l}\text { Coeliac disease } \\
\mathrm{N}\end{array}$ & $\stackrel{\mathbf{N}}{\mathbf{N}}$ & $\begin{array}{l}\text { No } \\
\text { No }\end{array}$ & $\begin{array}{l}\text { BOC } \\
\text { BOC }\end{array}$ \\
\hline 11 & $\mathbf{M}$ & 18 & 8 years & Partial & $\begin{array}{l}\text { No malabsorption } \\
\text { symptoms }\end{array}$ & $\mathbf{N}$ & $\mathbf{N}$ & No & BOC \\
\hline 12 & $\mathbf{M}$ & 11 & 3 years & Partial & $\begin{array}{l}\text { No malabsorption } \\
\text { symptoms }\end{array}$ & $\mathbf{N}$ & $\mathbf{N}$ & No & BOC \\
\hline 13 & $\mathbf{F}$ & 6 & 2 years & Partial & $\begin{array}{l}\text { No malabsorption } \\
\text { symptoms }\end{array}$ & $\mathbf{N}$ & $\mathbf{N}$ & No & \multirow{2}{*}{$\begin{array}{l}\text { BOC + right } \\
\text { frontal Ca } \\
\text { BOC }\end{array}$} \\
\hline 14 & $\mathbf{M}$ & 10 & 3 years & Partial & $\begin{array}{l}\text { No malabsorption } \\
\text { symptoms }\end{array}$ & Not performed & $\mathbf{N}$ & No & \\
\hline 15 & $\mathbf{F}$ & 23 & 7 years & \multirow{6}{*}{$\begin{array}{l}\text { Generalised and } \\
\text { Partial epilepsy } \\
\text { Generalised and } \\
\text { Partial epilepsy } \\
\text { Generalised and } \\
\text { Partial epilepsy } \\
\text { Generalised and } \\
\text { Partial epilepsy } \\
\text { Convulsive status } \\
\text { Epilepticus } \\
\text { Not epileptic }\end{array}$} & 1 year & Coeliac disease & \multirow{2}{*}{$\begin{array}{l}\text { Bil restriction } \\
\text { or visual field } \\
\mathrm{N}\end{array}$} & Mild & BOC \\
\hline 16 & $\mathbf{F}$ & 23 & 1 year & & $\begin{array}{l}\text { No malabsorption } \\
\text { symptoms }\end{array}$ & Coeliac disease & & Mild & BOC \\
\hline 17 & $\mathbf{F}$ & 13 & 9 years & & $\begin{array}{l}\text { No malabsorption } \\
\text { symptoms }\end{array}$ & Coeliac disease & $\mathbf{N}$ & Mild & BOC \\
\hline 18 & $\mathbf{M}$ & 21 & 3 years & & 6 months & Coeliac disease & $\mathbf{N}$ & Mild & BOC \\
\hline 19 & $\mathbf{M}$ & 9 & 4 months & & $\begin{array}{l}\text { No malabsorption } \\
\text { symptoms }\end{array}$ & Not performed & $\mathbf{N}$ & No & BOC \\
\hline 20 & $\mathbf{M}$ & 10 & - & & & Coeliac disease & $\mathbf{N}$ & No & BOC \\
\hline
\end{tabular}

${ }^{\star} \mathrm{N}=$ Normal $; \mathrm{BOC}=$ Bilateral occipital calcifications; $\ddagger \mathrm{Ca}=$ Calcifications; $\S=$ Patients.

patients into two groups: one group consisted of 14 patients with partial epilepsy; the other consisted of 4 patients with both generalised and partial seizures.

\section{PARTIAL EPILEPSY}

Among the 14 patients with partial epilepsy, the mean age at onset of the seizures was $5 \cdot 2$ years (range seven months-16 years). In this early phase, 3 patients showed versive seizures, 6 patients presented simple and/or complex visual seizures, 3 patients showed partial complex seizures without clear visual symptoms, and 2 had generalised tonic-clonic seizures. The frequency of the seizures was irregular, with a tendency for them to appear in clusters.

Four patients had repeated episodes of status epilepticus, partial (cases 1,2, and 4) or generalised (case 3 ).

In this early stage EEG was available for only 10 of the 14 patients. It showed normal background activity and the presence of spikes and/or spikes and waves in one or both parieto-occipital regions, enhanced by eyes closure. These abnormalities were not activated during sleep. In patient 12 the EEG showed generalised spike and wave discharges.

The epilepsy did not follow the same course in all 14 patients: in 6 patients (cases $1,4,6,8,13$ and 14), now aged between six and 16 years, the seizures stopped after treatment, at a mean age of 5.9 years (range 2-15 years) and they have not recurred, though treatment with antiepileptic drugs had been discontinued. In cases $2,3,5,9$, and 12 , now aged between 11.5 and 23 years, the seizures disappeared at an average age of 5.6 years (range 3-7.5 years), but they recurred between six and 14 years, after an average seizure-free interval of 4.8 years (range $1-9 \cdot 5$ years). In cases 7,10 and 11 , seizures persisted in spite of the treatment.

Among those patients whose seizures persisted or recurred, the attacks remained partial (versive, visual or partial complex), one patient had more than one type of partial seizure. Cases 10, 11 and 12 also had convulsive generalised seizures. Seizure frequency was low on the antiepileptic drugs, with the exception of case 9, who continued to have several seizures a day, often induced by eating.

In the late phase, irrespective of the seizure outcome, the EEG showed the persistence of paroxysmal abnormalities in all but one case (case 2). These were localised to one or both posterior regions, and could take the form of pseudoperiodical asynchronous slow spikes or slow spike-slow wave complexes.

During sleep a marked bilateral spread of these abnormalities was observed, with the appearance of frequent bursts of diffuse slow spike-slow wave complexes.

\section{Generalised and partial epilepsy}

Four patients had a severe form of epilepsy. The seizures appeared at a mean age of $5 \cdot 2$ years (range 1-9 years). At the onset 3 patients showed partial seizures, versive and/or visual, and 2 of these also had absences (cases 17 and 18). The fourth patient had both partial and generalised (tonic) seizures (case 16). At this early stage, neurological examination and intellectual level were normal in all patients. In all cases seizures were frequent at onset, occurring 
daily or more than once a day. The EEG, available for 2 patients, was distinctly abnormal, showing asynchronous spike and wave complexes in both occipital regions, spreading bilaterally during sleep.

During the course of the illness, the seizure frequency continued to be high in 2 patients (cases 15 and 18), despite treatment. In the other 2 cases (16 and 17), the seizures stopped after treatment, but recurred, after a seizure-free period of one year and five years respectively. There was a progressive deterioration of the seizures with time, with the appearance of polymorphous, partial and convulsive generalised seizures, and partial seizures with falls. Atypical absences were present in all cases. One patient also experienced prolonged complex partial status epilepticus. Seizures were frequent and drug-resistant in all cases. Concomitantly, intellectual deterioration occurred, while neurological examination remained unchanged.

EEG was distinctly pathological in all cases, showing bilateral and asynchronous slow spike and slow wave complexes in both temporo-parieto-occipital regions and long bursts of secondarily diffused slow spike and slow wave complexes. These abnormalities were clearly enhanced by eye closure and were attenuated by eye opening. The multifocal and diffuse abnormalities, observed during wakefulness, persisted during sleep and diffuse discharges of fast polyspikes-slow wave complexes appeared.

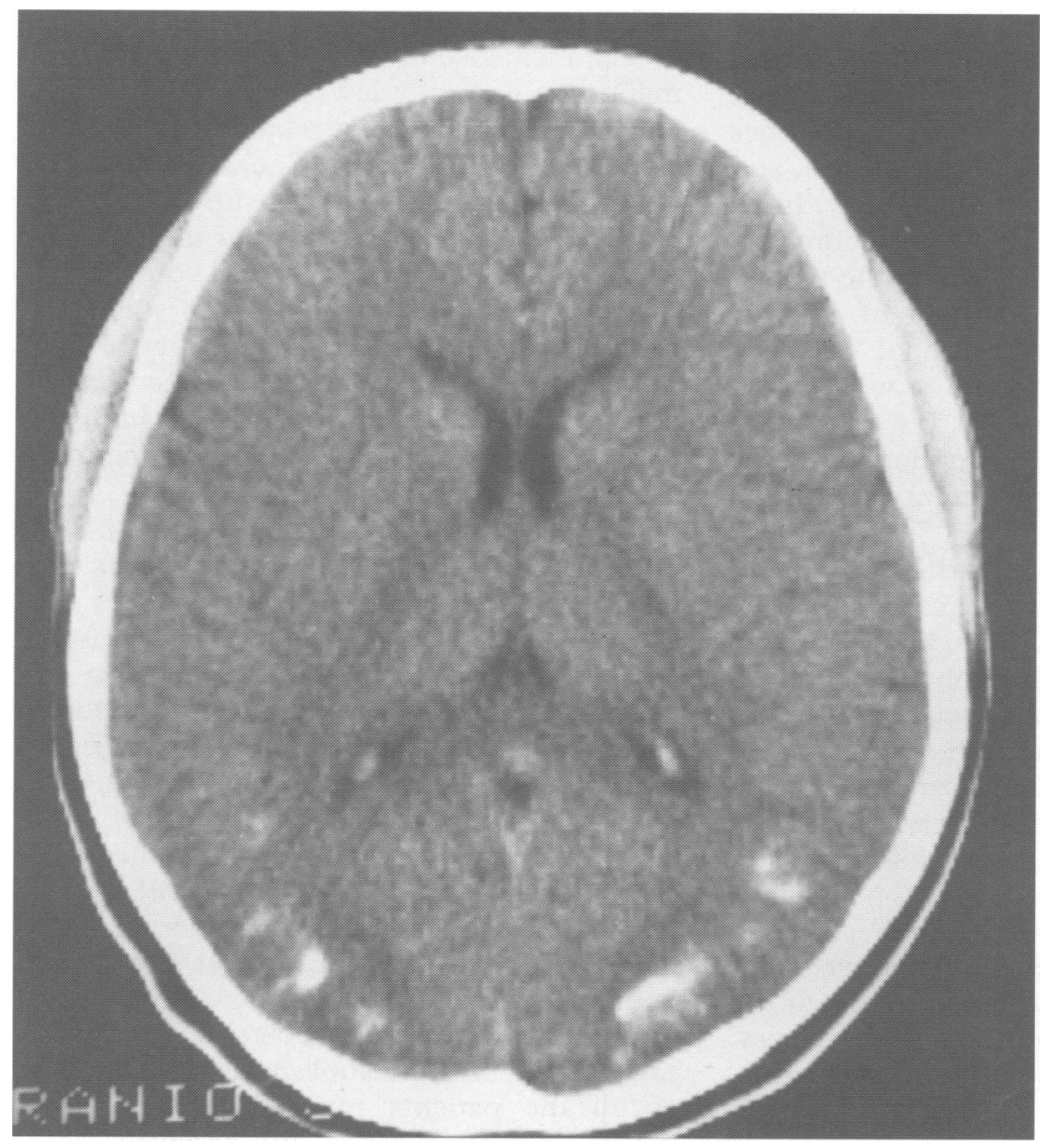

Figure 1 Case 3-CT scan showing bilateral, cortico-subcortical, parieto-occipital calcification.

\section{NEUROIMAGING}

The first CT scan was performed at a mean age of 8.6 years (range 2-19 years). In 18 patients it revealed bilateral, flocculo-nodular, cortico-subcortical $\mathrm{Ca}$ which were confined to the parieto-occipital regions in 15 patients (fig 1), while 3 patients (cases 1, 4, and 13) showed more extensive $\mathrm{Ca}$ spreading to the anterior regions (fig 2). In cases 10 and 12 the first CT scan, performed when they were respectively two and three years old, was nor$\mathrm{mal}$ in case $10 \mathrm{BOC}$ appeared at four years of age; in case 12, CT showed unilateral left parieto-occipital calcification at six years, and BOC at 11 years. There was no enhancement after the injection of contrast and no atrophy was detected in the cortical areas adjacent to the $\mathrm{Ca}$ (figs 1 and 2).

Control CT, performed after a mean period of $2 \cdot 3$ years, did not show a significant alteration in the size or extent of $\mathrm{Ca}$ in 13 patients. In cases $1,2,5,10,12,13$, and 14 it revealed a significant extension of the $\mathrm{Ca}$. Skull radiographs revealed the presence of $\mathrm{Ca}$ in only 4 patients. MRI failed to reveal $\mathrm{Ca}$ or focal atrophy in any patient even after administration of contrast medium. Cerebral angioscintigraphy, digital angiography and SPECT were normal.

\section{Malabsorption syndrome}

In 8 of the 16 cases studied, intestinal biopsy showed atrophy of the villi compatible with a diagnosis of coeliac disease. Three of these 8 patients (cases 1, 15 and 20) had presented the typical symptoms of malabsorption during infancy although when they were referred to us these were no longer apparent. The patients' histories indicated that only case 1 had had a gluten-free regime, and shortly after starting this the epileptic seizures disappeared.

In the remaining 5 patients (cases $7,9,16$, 17 and 18), who had not showed the typical symptoms of malabsorption, the diagnosis of CD was made on the basis of the intestinal biopsy performed after the detection of BOC. In 2 of these 5 patients the diet, begun three and five years respectively after seizure onset, had no effect on seizure frequency. For the other 3 patients no details regarding the administration of the diet were available.

Of the 8 patients in whom intestinal biopsy was normal, two presented symptoms of malabsorption during infancy. Neither had ever been on a gluten-free regime (cases 3 and 6).

The malabsorption symptoms appeared before epileptic seizures in all but one of the patients.

\section{Discussion}

Nineteen of the 20 patients (95\%) affected by BOC had epilepsy, and many of them (50\%) had a malabsorption syndrome. It is therefore clear that they form a clinical syndrome.

The symptom which led to neuroradiological investigations was epilepsy, but the clinical picture of this process is variable. We have been able to identify 2 groups of patients with 


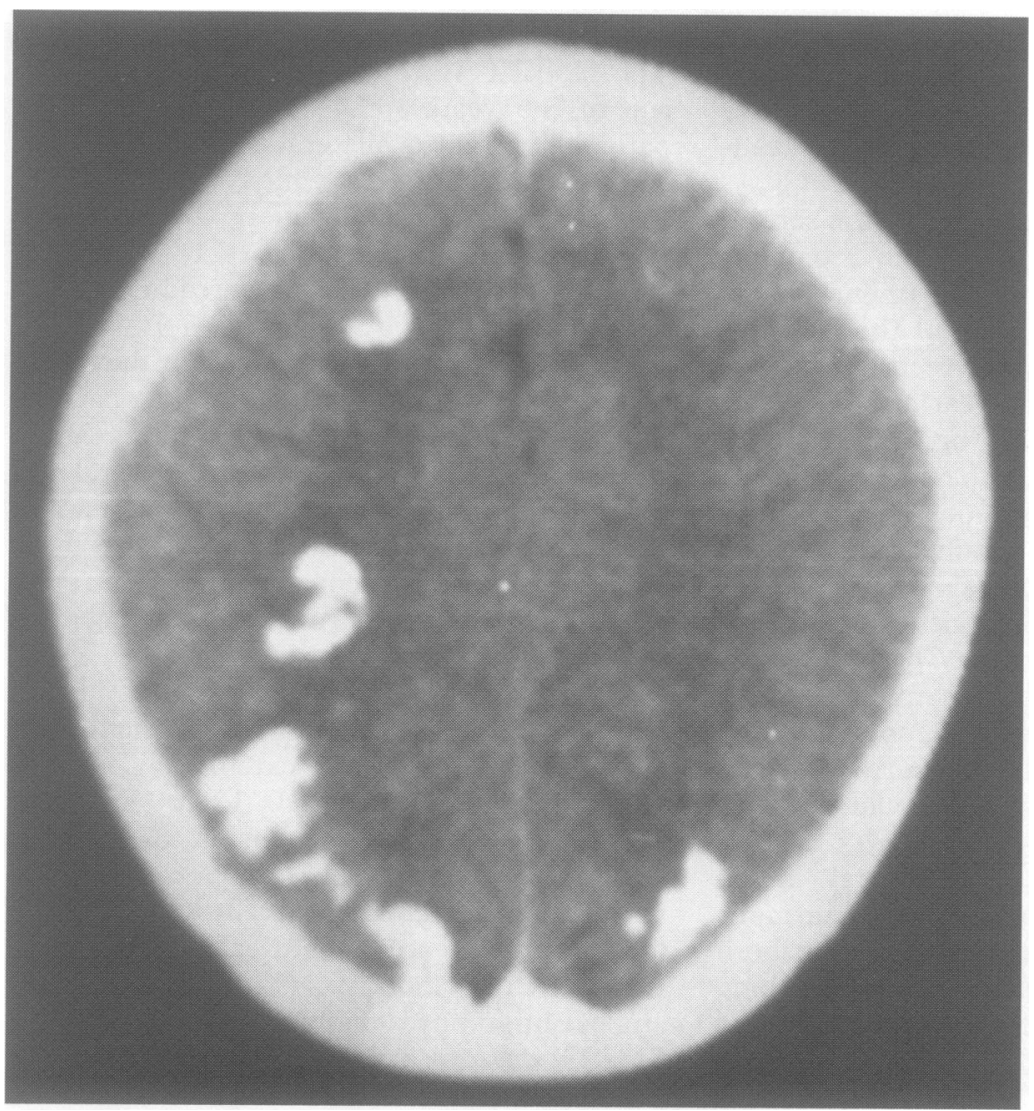

Figure 2 Case 1-CT scan showing cortico-subcortical bilateral calcification in occipital, parietal and frontal regions.

quite different clinical courses: the first group (14 patients) had partial epilepsy with occipital seizures. In these cases the epilepsy was particularly active in the early phase, during which status epilepticus also occurred, but it has a relatively benign prognosis. Sometimes the seizures disappeared entirely, sometimes recurred after a long seizure-free interval, and sometimes persisted at a low frequency. In all cases the intellectual level and the neurological examination remained normal; the second group (4 patients) had an onset of epilepsy characterised by partial occipital seizures. After an initial phase, and with or without the seizure-free interval, frequent, polymorphous and drug-resistant seizures developed. These patients all showed concomitant intellectual deterioration.

The evolution of this second group is similar to that reported in some cases of $\mathrm{BOC}^{9}$ and in particular by Gobbi et al. ${ }^{1}$ Partial occipital epilepsy which evolves towards a pattern of epileptic encephalopathy has also been observed in patients with occipital calcifications due to toxoplasmosis or therapy with intrathecal methotrexate and cranial irradiation, as well as in patients showing no occipital calcification. ${ }^{20}$

The factors which determine such an important difference in evolution between our two groups are not clear: there is no difference in mean age of onset of the epilepsy; there is no correlation between the seriousness of the epilepsy and the extent of the calcification; there is no clear correlation between the seriousness of the epilepsy and the presence or absence of CD.
We believe that patients with BOC can be easily differentiated from those with SWs on the basis of the following characteristics. Clinically:

The absence of cutaneous signs of phakomatosis.

Absence of neurological deficit, which does not appear either as a result of prolonged partial seizures, or in patients with serious epilepsy.

Neuroradiologically:

The absence of lobar or hemispheric atrophy which is almost always present in SWs. ${ }^{22}$

The constantly bilateral localisation of $\mathrm{Ca}$, which is seen in only $15-19 \%$ of patients with SWs. ${ }^{23}$

The absence of contrast enhancement, which is always present in SWs. ${ }^{22}$

The cortico-subcortical locus of BOC, against the mainly cortical locus in SWs.

A normal MRI in BOC as against the abnormal MRI in SWs, where it usually shows a lobar or hemispheric atrophy in relation to the site and the size of the angioma. ${ }^{24}$

The high prevalence of a malabsorption syndrome detected in our patients and in the literature $e^{14-1925}$ is particularly remarkable since epilepsy is such a rare symptom in patients with CD. Patients with $C D$ do not usually present any neurological complications which would lead to a cerebral CT and the eventual discovery of BOC. Chapman et $a l^{26}$ reported a higher prevalence of epilepsy in patients with $\mathrm{CD}(5,5 \%)$, than in a control group $(0,5 \%)$. Unfortunately, the cases were not extensively described nor has this observation been confirmed by subsequent studies.

The incidence of other neurological abnormalities is generally low in subjects with $C D$ and their aetiological correlation with the $C D$ is not clear. ${ }^{27}$ In 1966 Cooke and Smith ${ }^{28}$ reported 16 adult patients with coeliac disease, affected by dysfunction of the posterior and lateral columns of the spinal cord. In 9 of these patients, whose brains were studied at necropsy, degenerative processes were seen not only in the spinal cord, but there was also cortical and cerebellar atrophy. In these patients, a causal role of specific vitamin deficiencies could not be established.

The aetiological correlation between BOC and folic acid deficiency, which has been proposed by many authors, ${ }^{41417-19}$ does not seem plausible to us for the following reasons: the presence of intracranial calcification was not generally observed; the rare reported cases of patients affected by a congenital defect of the metabolism of folic acid who also had neurological signs. ${ }^{29}$ They were reported in only one patient ${ }^{30}$ and they were localised to the basal ganglia and had a punctiform, instead of flocculo-nodular morphology; the supposed aetiological correlation between intracranial $\mathrm{Ca}$ and intrathecal methotrexate treatment, caused by an inhibition of folic acid metabolism, is questionable, as all the patients reported in the literature, ${ }^{31-37}$ except $2,{ }^{34}$ had also received radiotherapy together with methotrexate; folic acid deficiency is not observed in all patients with 
$B O C$ and $C D$, and it is not present in patients with BOC who do not have CD.

The high prevalence of $\mathrm{CD}$ in patients with BOC is reminiscent of the association between $C D$ and dermatitis herpetiformis $(\mathrm{DH})$. All or almost all the patients affected by $\mathrm{DH}$ also have $\mathrm{CD}$, clinical or subclinical, while only a limited number of patients with $\mathrm{CD}$ have $\mathrm{DH} .^{38}$ As in $\mathrm{CD}$ without skin lesions, the prevalence of the histocompatibility antigens HLA-B8, and HLA-DQw2 is much higher in patients with $\mathrm{DH}$ than in normal individuals. This suggests that $\mathrm{DH}$ and $\mathrm{CD}$ are two distinct diseases, probably connected by the same genetic factor. ${ }^{39}$

HLA studies were carried out in only 3 of our patients, 2 with CD and 1 without. They all showed the presence of the histocompatibility antigens HLA-DR7 and DQw2, which are strongly associated with the susceptibility to $\mathrm{CD} .{ }^{40}$ These preliminary findings suggest that a similar HLA pattern may cause the susceptibility both for $\mathrm{CD}$ and BOC.

\section{Conclusions}

Patients with BOC have epilepsy which can vary from partial epilepsy, confined to the first years of life, to serious long lasting epilepsy and intellectual deterioration.

Patients with BOC are clearly distinguishable from those with SWs not only on the clinical level, but also on the basis of neuroimaging.

The high prevalance of a malabsorption syndrome in patients with BOC is established, but the causal relationship between these two pathologies still needs to be clarified.

It seems justifiable therefore to consider the association of BOC, epilepsy and, in some cases $C D$, as a distinct entity.

1 Gobbi G, Sorrenti G, Santucci M, Giovanardi-Rossi P, Ambrosetto P, Michelucci R, Tassinari CA. Epilespy with bilateral occipital calicifications. A benign onset with progressive severity. Neurology 1988;38:913-20.

2 Magaudda A, Meduri M, Longo M, Daniele O, Tortorella G, Dalla Bernardina B. The syndrome of bilateral occipital calcifications (BOC) epilepsy and bilateral occipital calcifications (BOC) epilepsy and coeliac disease: clinical and neuroimaging fe

3 Magaudda A, Colamaria V, Narbone MC, Capizzi G Landre E, De Domenico P, Dalla Bernardina B Calcificazioni occipitali bilaterali senza nevo flammeo: studio di 8 casi. Boll Lega It Epil 1990;70/71:251-54.

4 Garwicz S, Mortensson W. Intracranial calcification mim icking the Sturge-Weber syndrome. A consequence of cerebral folic acid deficiency? Pediat Radiol 1986;5:5-9.

5 Gugliantini P, Carnevale E, Fariello G, Rosati D Donfrancesco A, Miano C, Sagui G. Calcificazioni endocraniche simulanti 1a sindrome di Sturge-Weber. Riv Ital Ped (IJP) 1980;5:851-55.

6 Ambrosetto P, Ambrosetto G, Michelucci R, Bacci A, Sturge-Weber syndrome without port-wine facial nevus. Sturge-Weber syndrome witho
Child's Brain 1983;10:387-92.

7 Sammaritano M, Andermann F, Helanson D, Guberman A, Tinuper P, Gastaut $H$. The syndrome of epilepsy and bilateral occipital cortical calcifications. Epilepsia 1985;26:532.

8 Pagani M, Arietti V, Benvenuti C, Lonfranchi V, Valseriati D. Un caso atipico di Sturge-Weber-Krabbe con calcificazioni intracraniche bilaterali in assenza di angiomatosi cutanea. In: Benedetti P, Curatolo P, Ottaviano S, eds. Atti del VII Convegno di Neurologia Infantile. Roma: Sigma Tau, 1986:110.

9 Piattella L, Zamponi N, Cenci L, Rossi R, Papa O. Calcificazioni bioccipitali ed epilessia: malattia di Sturge-Weber atipica o nuova sindrome? Boll Lega It Epil 1986;54/55:139-42.

10 Ciarmatori C, Alesi C, Micholucci R, Tassinari CA Epilessia e calcificazioni occipitali: un caso con crisi rifEpilessia e calcificazioni occipitali: un caso con cris

11 Giroud M, Borsotti JP, Michiels R, Tommasi M, Dumas R. Epilepsie et calcifications occipitales bilaterale: 3 cas. R. Epilepsie et calcifications occipital

12 Battistella PA, Mattesi P, Casara GL, Carollo C, Condini A, Allegri F, Rigon F. Bilateral cerebral occipital calcifi- cations and migraine-like headache. Cephalalgia 1987;7:125-28

13 Del Giudice E, Romano A, Pelosi L, Napolitano E, Diano A. Bilateral cerebral posterior calcifications and epilepsy: atypical Sturge-Weber or a new nosological entity? In: Faienza C, Prati GL eds. Diagnostic and therapeutic In: Faienza C, Prati GL, eds. Diagnostic and therapeutic problems in pediatric epilepto

14 Sammaritano M, Andermann F, Melanson D, Gubermann A, Tinuper P, Gastaut H. The syndrome of intractable epilepsy, bilateral occipital calcifications and folic acid deficiency. Neurology 1988;38(suppl 1):239.

15 Giroud M, Nivelon-Chevalier A, Vicard C, Couailler JF, Dumas R. Epilepsie et calcifications corticales occipitales bilaterales. Une entité nouvelle. La Presse medicale 1987;6:308-9.

16 De Marco P, Lorenzin G. Growing bilateral occipital calcifications and epilepsy. Brain Dev 1990;12:342-4.

17 Zaniboni MG, Lambertini A, Romeo N, Conti $R$ Ambrosioni G. Celiac diasease and epilepsy with occipiAmbrosioni G. Celiac diasease and epilepsy with occipiItalian Paediatric Gastroenterology, Joint Meeting, Parma, Italian Paediatric

18 Ventura A, Barbi E, Bouquet F, Tommasini G, Sartorell C. Calcificazioni endocraniche ed epilessia occipitale Una consequenza della celiachia? Proc $X V$ National Congress of Italian Society of Neuropediatrics, Florence (Italy), November, 1989.

19 Piattella L, Zamponi N, Porfiri L. Calcificazioni cerebral multiple e celiachia. Boll Lega It Epil 1990;70/71: 263-264.

20 Magaudda A, Colamaria V, Landré E, Dalla Bernardina B. Epilepsie occipitale et encéphalopathie épileptogène. Neurohysiol Clin 1989;19:353.

21 Magaudda A, Longo M, Dalla Bernardina B, Blandino A Capizzi G, Meduri $M$. Neuroimaging nella sindrome delle calcificazioni occipitali bilaterali senza nevo flammeo (COBsNF): diagnosi differenziale con la sindrome di Sturge-Weber (SSW). Proc National Congress of Italian di Sturge-Weber (SSW). Proc National Congress of It
Society of Neurology. Siena, Italy, November, 1990.

22 Dieber C, Dulac O. Neurocutaneous syndromes. In Diber C, Dulac D, eds. Pediatric Neurology and Neuroradiology. Cerebral and cranial diseases. Berlin Heidelberg: Springer-Verlag, 1987:85-104.

23 Boltshauser E, Wilson J, Hoare RD. Sturge-Weber syndrome with bilateral intracranial calcification. $f$ Neurol Neurosurg Psychiatry 1976;39:429-35.

24 Naidich TP, Zimmermann RA. Common congenital malformations of the brain. In: Brant-Zawadzki $\mathbf{M}$, Norman D, eds. Magnetic resonance imaging of the central norvous system. New York: Raven Press, 1987:125-50.

25 Gobbi G, Tassinari CA. Calcificazioni corticali-sottocorticali occipitali bilaterali simulanti la sindrome di StugeWeber associate a epilessia e sindrome de malassorbimento. Riv neuroradiol 1990;3 (suppl 1):108.

26 Chapman RWG, Laidlow SM, Colin-Jones D. Increased prevalence of epilepsy in coeliac disease. $B M^{\mathfrak{F}}$ 1978;2:250-1.

27 Cooke WT. Neurologic manifestations of malabsorption. In: Vinken PJ, Bruyn GW. eds. Handbook of clinical neurology. Amsterdam: North Holland, 1976;28:225-41. 8 Cooke WT, Smith WT. Neurological disorders associated with adult coeliac diasease. Brain 1966;89:683-722.

29 Niederwieser. Inborn errors of pterin metabolism. In Botez MI and Reynolds EH, eds. Folic acid in neurolog, psychiatry and internal medicine. New York: Raven Press, psychiatry and

30 Lanzkowsky P. Congenital malabsorption of folate. $\mathrm{Am} \mathcal{F}$ Med 1970;48:580-3.

31 Borns PF, Rancier LF. Cerebral calcification on childhood leukemia mimicking Sturge-Weber syndrome. $\mathrm{Am}$ f Roentgenol 1974;122:52-55.

32 Spehl M, Flament J, Maurus R, Delalieux G, Brihaye J, Cremer N. Calcifications intracraniennes diffuses appairaissant à la suite d'une leucémie aigue. Ann Radiol 1974;17:417-22.

33 Flament Durant J, Ketelbant-Balasse $\mathbf{P}$, Maurus $\mathbf{R}$ Regnier R, Spehl M. Intracerebral calcifications appearing during the course of acute lymphocitic leukemia treated with methotrexate and X-rays. Cancer 1975;35:319-25.

34 Mueller S, Bell W, Seibert J. Cerebral calcifications associated with intrathecal methotrexate therapy in acute ciated with intrathecal methotrexate therapy in

35 Young LW, Jequier S, O'Gorman AM. Intracerebral calcifications in treated leukemia in a child. $A m \mathcal{F}$ Dis Child 1977;131:1284-5.

36 Smith D, Bloch S, Al-Rashid RA. Basal ganglia calcification on CT scanning in children with acute lymphocytic leukemia. Neuroradiology 1980;20:91-93.

37 Colamaria V, Tatò L, Avanzini S, Capovilla G, PajnoFerrara F, Dalla Bernardina B. Complicazioni tardive della radioterapia nei tumori cerebrali infantili. Riv It Ped (IJP) 1985;11:406-11.

38 Brow J, Parker F, Weinstein WM, Rubin CE. The small intestinal mucose in dermatitis herpetiformis. Severity and distribution of the small intestinal lesion and associated malabsorption. Gastroenterology 1971;60:355-61.

39 Sachs JA, Awad J, McCloskey D, et al. Different HLA associated gene combinations contribute to the susceptibility for coeliac disease and dermatitis herpetiformis. GUT 1986;27:515.

40 Koskimies S, Lipsanen V, Maki M, Visakorpi J. HLA and coeliac disease, a finnish family study. In: Mearin ML and Mulder CJJ, eds. Coeliac disease, 40 years gluten-free. Dordrecht: Kluwer Academic, 1991:9-13. 